\title{
Aleksandra Machura
}

Karol Lipiński ACAdemy of Music in WrocŁaW

\section{Jadwiga Szajna-Lewandowska for Children}

\section{Abstract}

In the second half of the twentieth century, music for children was enriched by the works of Jadwiga Szajna-Lewandowska (1912-1994). The Wrocław's pianist, composer and pedagogue wrote most of her pieces for the youngest and thus the most sensitive recipient. The vast majority of her works is stage music for children, mainly ballet. In this category, Szajna-Lewandowska has no equal. She is the one of the rare composers who devoted most of their works to children. Her music for the youngest comprises not only stage works, but also compositions written for children as performers or listeners. Among them, there are instrumental, vocal-instrumental and choral pieces. Therefore, it can be claimed that Jadwiga Szajna-Lewandowska is a composer who made a significant contribution to Polish children's and young adult literature.

\section{Keywords}

2oth-century Polish music, music for children, genres of stage music, music pedagogy 
A child is the most eager to know the world, sensitive, and simultaneously the most critical recipient. Among all branches of art, music is the one which demands the most developed imagination from the creator, if he or she wants to write the work, which will inspire the listener. Children can flawlessly unmask everything, what is false in the word, music or dance. Therefore, it is not surprising that among Polish composers writing also for children, there are such great artists as Witold Lutosławski, Tadeusz Baird, Andrzej Panufnik or Krzysztof Meyer. However, in this field Jadwiga Szajna-Lewandowska should be distinguished, the author who wrote most of her pieces indeed for children.

Jadwiga Szajna-Lewandowska was born on 22th February 1912 in Brody (currently in Ukraine), and died on 14th March 1994 in Wrocław. At the age of 7 , she started her piano education with Lviv's pianist and pedagogue, Helena Ottawowa, which was next continued with Maria Sołtysowa in Conservatory of Polish Association of Music in Lviv. Her first composition lessons were given by the known conductor, pedagogue and Lviv's composer - Adam Sołtys. She continued education after the war at the State High Music School in Wrocław, firstly under the guidance of Tadeusz Szeligowski, then Piotr Perkowski, and next Stefan Bolesław Poradowski. She graduated from State High Music School in Wrocław in 1956 and since then devoted herself to the compositional work, in which ballet and theatre music for the youngest was important. Szajna-Lewandowska worked also as a pedagogue in the field of piano, theory of music and propedeutics of composition in Lviv, Lublin and Wrocław. It was Wrocław where she moved; she composed there and was active in many musical organizations, among others she was Director of the Wrocław Branch of Polish Composers' Union. As the acknowledgement of her activity were numerous awards and distinctions, among others, in 1965 - the Award of City of Wrockaw for lifetime achievement, and in 1974 the Award of the Prime Minister for the work for children. She was awarded several times, e.g. during the compositional competitions "Olope's Spring", and given a distinction, including the Competition of Women Composers in Mannheim. ${ }^{1}$

Szajna-Lewandowska belongs to these rare composers who devoted most of their works to young listeners. The main area of her compo-

1 M. Słota, Szajna-Lewandowska Jadwiga, [in:] Kompozytorzy polscy 1918-20oo, M. Podhajski (ed.), Vol. 2, Biogramy, Gdańsk-Warszawa 2005, pp. 970-971. 
sitional activity are stage works for children, among which ballets are the most frequent:

In the work for children, I am interested in climate, especially fantasy, poetry and wit. I write for stage, because through movement, action, in my opinion, the musical piece becomes fuller. I may appear paradoxical, but creating I see the music and it is the reason for my inclination for stage compositions. ${ }^{2}$

Her first stage work is the ballet Pinokio, which she presented in 1956 as her dissertation. The composer explained her choice in the following way:

I have chosen a ballet, because this type of a form has been close to me for some time. Practically, I like stage music in general. I think that I just feel it [...]. I would like to give above all moments of happiness and smile to the children. It is my deepest dream. ${ }^{3}$

Pinokio is a ballet for children in three pictures with prologue and epilogue. In the work such characteristic features of the composer's style become visible as lightness, nicety, wit, jest and grotesque. The choice of the libretto edited by Irena Turska was caused by the theme of a known book written by the Italian writer Carl Collodi, full of colourful fantasy and pedagogical values. Music uses tone painting, is characterized by rich timbre, transparent texture and brilliant instrumentation. In order to mirror particular characters, the composer introduced the leitmotivs, which return during the ballet together with the entrance of the adequate character (example 1 and 2).

2 Orig. "W twórczości dziecięcej pociąga mnie klimat, przede wszystkim fantastyka, poetyckość i dowcip. Piszę dla sceny, gdyż poprzez ruch, działanie, w moim pojęciu, utwór muzyczny staje się pełniejszy. To może wyda się paradoksalne, ale tworząc widzę muzykę i stąd te moje ciągoty do kompozycji scenicznych". A. Dąbrowska, Ja widzę muzykę, "Gazeta Robotnicza", 20.06.1974, p. 5.

3 Orig. "Wybrałam balet, ponieważ ten właśnie rodzaj formy od dawna już był sercu memu bliski. Właściwie lubię muzykę sceniczną w ogóle. Wydaje mi się, że ją po prostu czuję [...]. Chciałabym dać dzieciom przede wszystkim chwile radości i uśmiechu. Jest to moje najskrytsze marzenie". J. Szajna-Lewandowska, Balet ten dedykowałam polskim dzieciom, [in:] Pinokio [programme of the play], Wrocław 1964. 


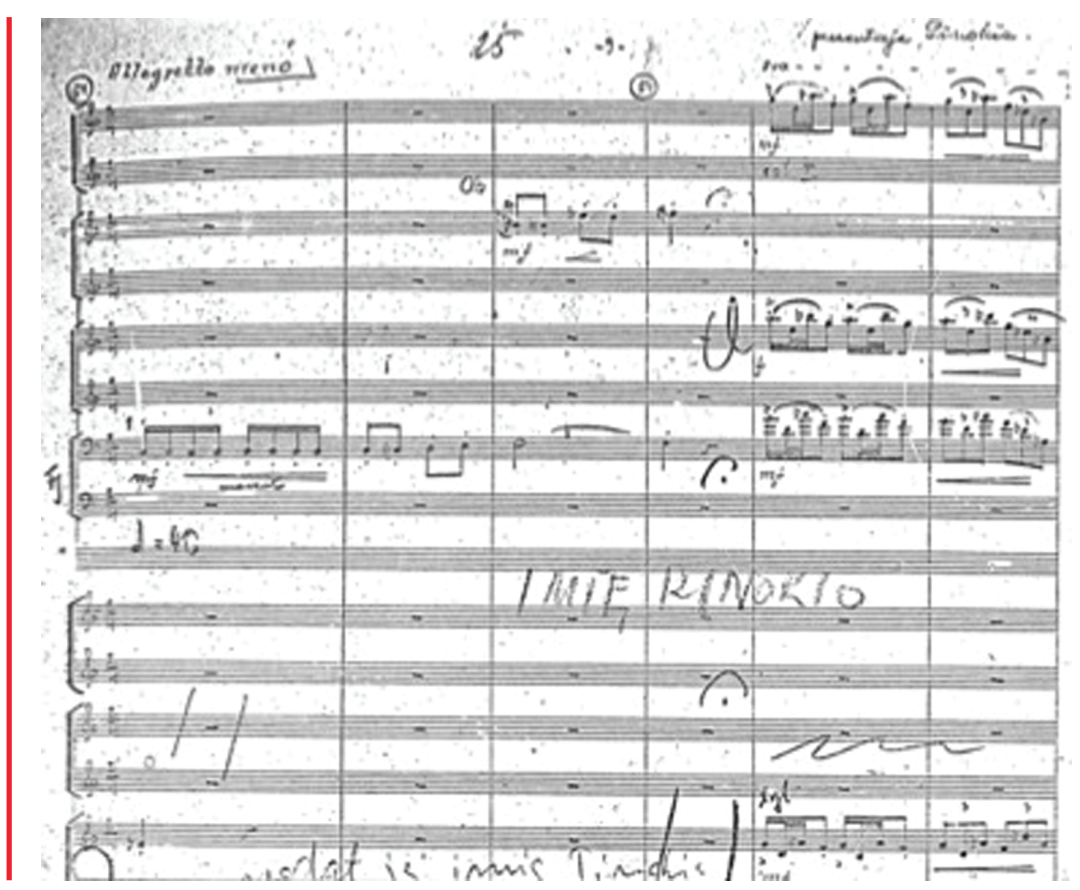

Ex. 1: Pinokio, Pinokio's motif (bb. 55-56). Source: J. Szajna-Lewandowska, Pinokio (xerocopy of a manuscript), Wrocław 1956, p. 25, bb. 51-56.

Premiere of Pinokio took place on 1st June 1964 on the stage of National Opera in Wrocław. It is how Ryszard Bukowski wrote about it:

After many years of waiting, the Wrocław's composer Jadwiga SzajnaLewandowska saw her ballet for children Pinokio on stage. The ceremonial premiere took place on the International Children's Day as the gift for children from the Department of Culture of National Counsel in Wrocław City and the National Opera in Wrocław. Lewandowska's music in Pinokio is without doubt the turning point in her career. It is perhaps the first mature work of our composer. The conscious choice of means, skillfully operated modernity of language with remaining the transparency, timbre and jest. The perfect characterization of the particular characters (especially Pinokio, Knot), shapely stylization and density - these are undoubtedly the advantages of music. ${ }^{4}$

4 Orig. "Po wielu latach oczekiwania doczekała się wrocławska kompozytorka Jadwiga Szajna-Lewandowska wystawienia swojego baletu dziecięcego Pinokio. Uroczysta premiera odbyła się w Międzynarodowym Dniu Dziecka jako dar dla 


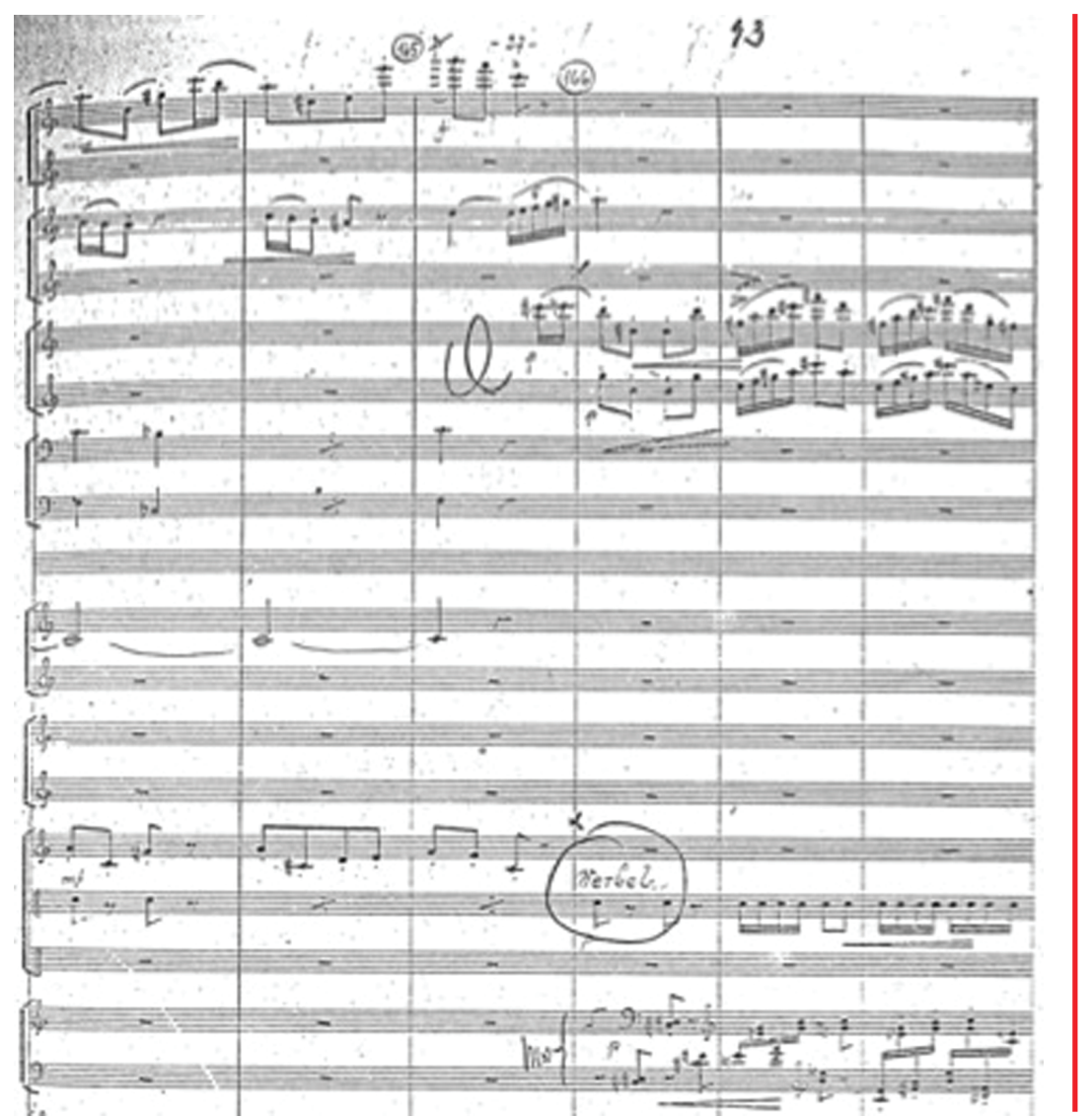

Ex. 2: Pinokio, Knot's motif (bb. 166-168). Source: J. Szazjna-Lewandowska, Pinokio (xerocopy of a manuscript), Wrocław 1956, p. 43, bb. 163-168.

It is worth adding that Pinokio was a success not only on Polish musical theatres' stages, but also abroad, e.g. in Görlitz.

dzieci od Wydziału Kultury Rady Narodowej miasta Wrocławia i Państwowej Opery we Wrocławiu. Muzyka Lewandowskiej stanowi w Pinokiu niewątpliwie punkt zwrotny w jej dotychczasowej twórczości. Jest to chyba pierwsze dojrzałe dzieło naszej kompozytorki. Świadomy dobór środków, umiejętnie dawkowana nowoczesność języka z zachowaniem przejrzystości, barwności i dowcipu. Doskonała charakteryzacja poszczególnych postaci (zwłaszcza Pinokio, Knot), zgrabna stylizacja i zwartość - to niewątpliwie walory muzyki”. R. Bukowski, [without title], "Gazeta Robotnicza", 11.06.1964. 
The next ballet for children is, made in 1965, Porwanie w Tiutiurlistanie. The libretto, based on the Wojciech Żukowski's novel, was written by Klara Kmitto. The ballet consists of three acts and is written for big symphonic orchestra. The premiere took place on 18th February 1967 in State Opera in Wrocław. It is what Jadwiga Szajna-Lewandowska said about the choice of the libretto:

The topic of Porwanie $w$ Tiutiurlistanie contains all elements of fantasy; besides, I liked the jest and the great grotesque of the character. But there is also a hidden element of lyrism - this selfless friendship of three characters, Pypcio, Lisiczka Chytruska and Kot Mysibrat. It was difficult to decide, from which plot we had to - although regretting it - resign. It was also difficult to solve such an important problem as deciding if Porwanie is a good topic to dance - I perhaps believed the choreographer, if I decided to write such broad and difficult work. ${ }^{5}$

Despite this doubts, Jadwiga Szajna-Lewandowska created the work, which brought her much artistic satisfaction, because it stimulated the rich child's imagination. Young listeners liked the ballet very much and for two years filled the Wricław's opera. Largely, this success was created by the action of the ballet, which is transparent, interesting, with many comic scenes, and also - or even mainly - music illustrating stage action (example 3 ). It is music that greatly highlights the fairy tale climate of the piece and the changes of emotions.

Critics positively assessed Porwanie w Tiutiurlistanie. As the confirmation of these words, I display the fragment of a review written by Ewa Kofin, which appeared after the premiere of a play:

Encouraged by the success of Pinokio - National Opera in Wrocław has recently included the second children ballet of Jadwiga Szajna-Le-

5 Orig. "Tematyka Porwania w Tiutiurlistanie zawiera w sobie wszystkie elementy fantastyki, podobał mi się poza tym humor i kapitalna groteskowość postaci. A jest też głęboko ukryta nuta liryzmu - ta bezinteresowna przyjaźń trzech bohaterów, Kaprala Pypcia, Lisiczki Chytruski i Kota Mysibrata. Trudno było zdecydować, $\mathrm{z}$ których wątków powieści trzeba było choć z żalem zrezygnować. Trudno było też rozstrzygnąć tak ważny problem, czy Porwanie jest dobrym tematem do tańczenia - chyba uwierzyłam choreografowi, skoro zdecydowałam się pisać pracę tak obszerną i naprawdę niełatwą". J. Szajna-Lewandowska, Głos ma kompozytor, [in:] Porwanie w Tiutiurlistanie [programme of the play], Wrocław 1967. 
wandowska, Porwanie $w$ Tiutiurlistanie, in its repertoire. [...] Jadwiga Szajna-Lewandowska is the only Polish composer who has ballets for children in the oeuvre. Her interest complies with the particular skills in this field. Lewandowska's ballet music is "convenient to dance" (performers feel comfortable like when performing traditional music), easy to catch for the child's ear. It does not suggest, however, the conservatism of the composer, who - although does not belong to avant-garde - is far from tonality, traditional schemes of construction and instrumentation. Timbre seems to be her specialty as well as the sound, which characterises the content. The composer feels comfortable in the climate of grotesque and jest, what - in the case of comic art, and generally Porwanie $w$ Tiutiurlistanie belongs to it - appears to be especially precious. ${ }^{6}$

Other ballets of the composer are: Gry dziecięce (1968), Jak pająk muchom buty szył (1979), Czerwony kapturek (1984), Spacerek po mieście (1984), Niefortunne zaloty (1989), Słowik cesarza chińskiego (1992) i Księżniczka na ziarnku grochu (1992). Jadwiga Szajna-Lewandowska’s stage music of for children comprises also other genres. Besides ballets, musical Księżniczka w oślej skórce (1972), musical fairy tale Błękitny kot (1975) and fantasy-historical show Zaczarowany krawiec (1977) should be mentioned.

The first stage work, in which Szajna-Lewandowska decided to introduce singing, was musical Księżniczka w oślej skórce. It was composed to the libretto of Hanna Januszewska based on the Charles Perrault's fairy tale. The play consists of three acts and takes circa two hours.

6 Orig. "Zachęcona powodzeniem Pinokia - Państwowa Opera we Wrocławiu włączyła ostatnio w swój repertuar drugi balet dziecięcy Jadwigi Szajny-Lewandowskiej Porwanie w Tiutiurlistanie. [...] Jadwiga Szajna--Lewandowska jest jedynym polskim kompozytorem uwzględniającym w swej twórczości balety o tematyce dziecięcej. Zainteresowania te pokrywają się u niej z resztą ze szczególnymi uzdolnieniami w tym kierunku. Muzyka baletowa Lewandowskiej jest „wygodna do tańczenia” (wykonawcy czują się w niej tak swobodnie, jak w tradycyjnej), łatwo uchwytna nawet dla ucha dziecka. Nie oznacza to jednak konserwatyzmu kompozytorki, która choć nie należy do awangardy, daleko odbiega od tonalności, tradycyjnych schematów konstrukcyjnych i instrumentacji. Jej specjalnością wydaje się kolorystyka, ponadto charakterystyka dźwiękowa treści. Kompozytorka świetnie czuje się w klimacie groteski i humoru, co w wypadku sztuki komicznej, a taką jest w zasadzie Porwanie w Tiutiurlistanie, okazuje się szczególnie cenne”. E. Kofin, Spektakl pełen pogody, "Słowo Polskie", 9.03.1967. 
Kwartalnik Młodych Muzykologów UJ, No. 37 (2/2018)

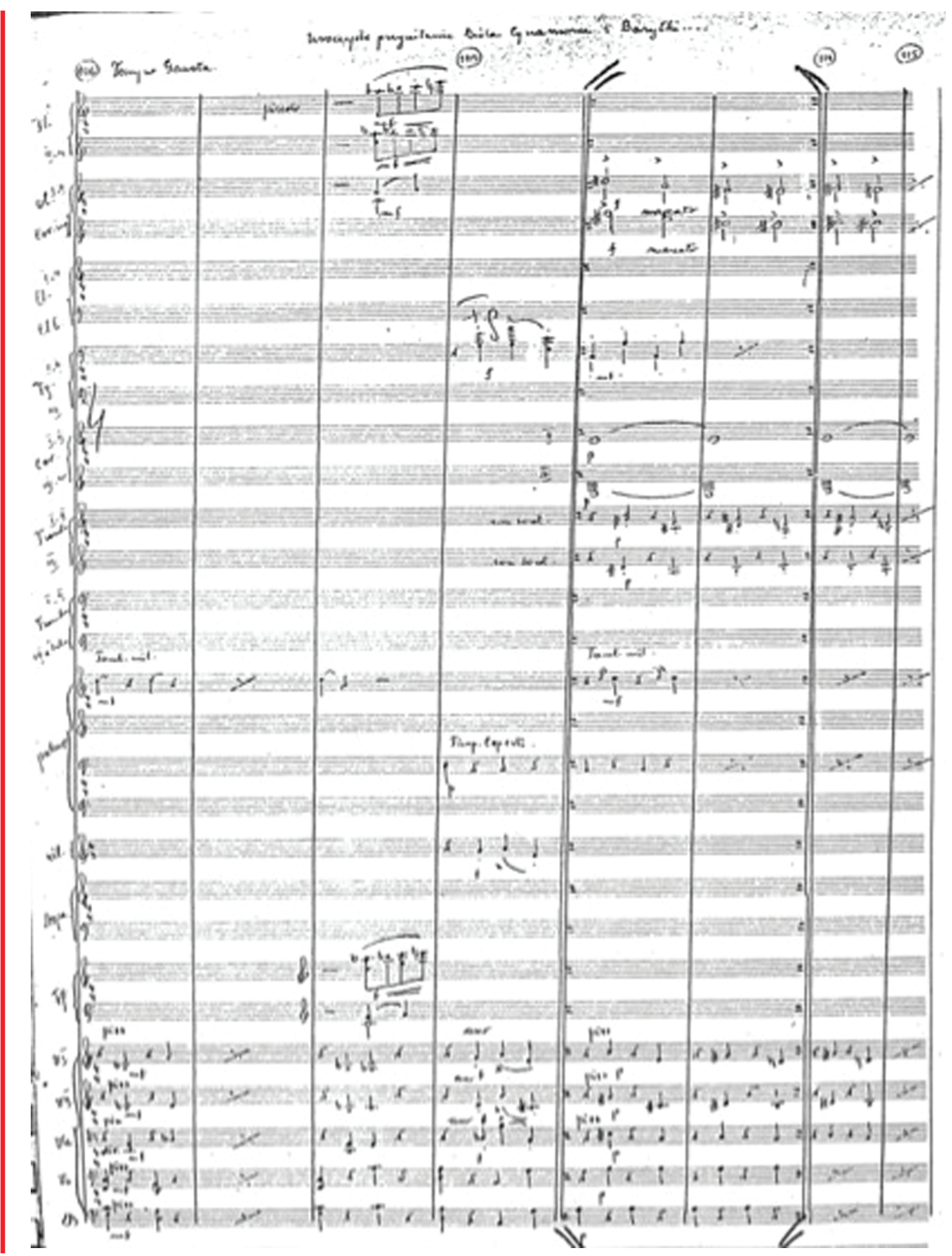

Ex. 3: Porwanie w Tiutiurlistanie, act I, bb. 106-115. Source: J. Szajna-Lewandowska, Porwanie w Tiutiurlistanie (xerocopy of a manuscript), Wrocław 1966, p. 15. 
Premiere took place on 3rd November 1975 in National Opera in Bytom. The music for the music is ear-catching, easy to listen, interestingly rhythmised and, what is important, with elements of modernity. In characteristic instrumentation, the composer used contrasting timbre of the particular instruments. This is the fragment of the review commenting the performance of Księżniczka w oślej skórce:

The ensemble of Opera Śląska presented colourful show, full of movement, enforcing the audience to react lively, especially in the finale of act II, when actors entrance the audience and encourage the listeners to play together. Young audience liked the rhythmical ariettas very much, children hums them even in the entracte of the performance. $^{7}$

The next show for the young audience is three-act musical fairy tale Błękitny kot, libretto for which, based on the East tale, wrote Tadeusz Zasadny. The piece was created in 1976, and the festive premiere took place on 31st January 1982 at stage of National Opera in Wrocław (illustration 1). Błękitny kot was written in two versions: for big symphonic orchestra, with the participation of a ballet, choir and soloist, and for chamber orchestra, choir soloists and ballet. The artist again perfectly engaged the imagination of the young recipient. The show was extraordinarily colourful, full of movement and expression. It was caused mainly by music of Jadwiga Szajna-Lewandowska. According to Ryszard Bukowski, the composer freely operated the means of modern dissonance harmony, used "the language of seconds and grotesque-sarcastic rhythms and melodies". ${ }^{8}$ The reviewer noticed that "this post-Prokofiev-like genre is dominant in Kot, penetrates it

7 Orig. “Zespół Opery Śląskiej zaprezentował niezwykle barwne widowisko, pełne ruchu, zmuszające widownię do żywych reakcji, szczególnie w finale II aktu, gdy aktorzy wychodzą na widownię i włączają publiczność do wspólnej zabawy. Młodym widzom niezwykle przypadły do gustu rytmiczne arietki, dzieci nucą je już w antraktach przedstawienia". A. Dąbrowska, [without title], "Gazeta Robotnicza", 12.12.1974.

8 Orig. "językiem sekund i groteskowo-sarkastycznych zwrotów rytmicznych i melodycznych”. R. Bukowski, „Błękitny kot” Szajny-Lewandowskiej, "Wieczór Wrocławia", 7.02.1982. 
fully in almost every scene. The layer of grotesque and jest was then totally grounded in music". 9

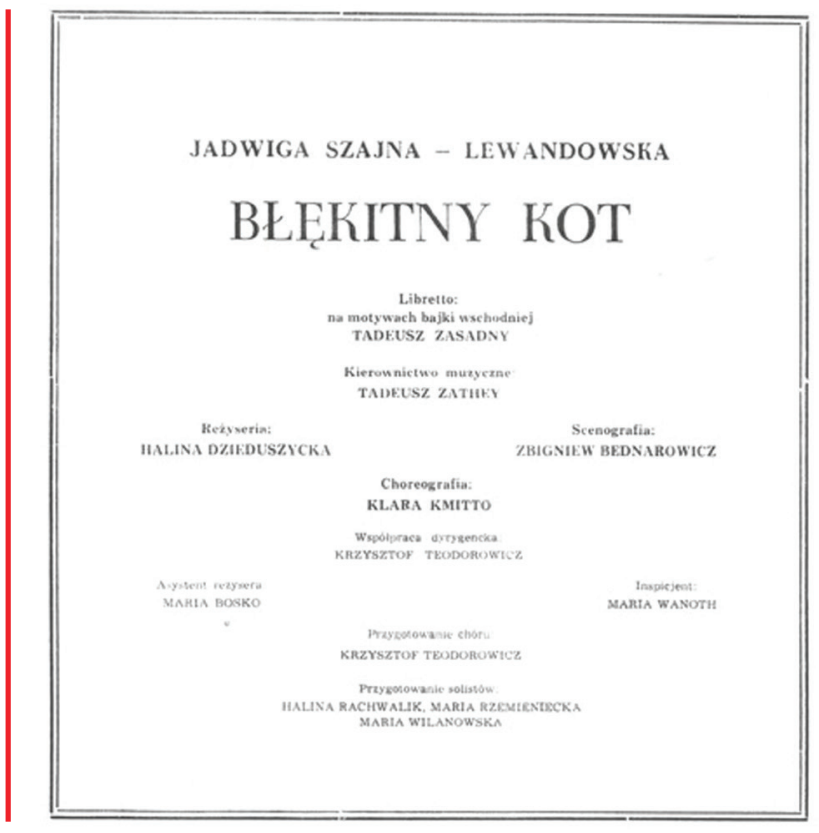

Illus. 1: J. Szajna-Lewandowska, Błękitny kot, a programme of the performance at the National Opera in Wrocław, Wrocław 1982.

The magnificent musical-ballet stage composition, the historicalfantastic show Zaczarowany krawiec was based on the libretto written by Janna Januszewska. The work was created for chamber orchestra, choir, soloists and ballet. It is a specific lesson of history, during which the composer presents different epochs through music (from the Middle Ages to the modernity). So, stylized Italian dances - pavane and tarantella - can be heard, as well as French - gavotte and canary dances, national Polish dances - polonaise and mazur, and modern dances.

Music for children in Szajna-Lewandowska's oeuvre is not only stage work, but also compositions written from children as perform-

9 Orig. "Ten postprokofiewowski genre dominuje w Kocie, przenika go bez reszty niemal w każdej scenie. Warstwa groteski i humoru znalazła więc całkowite oparcie w muzyce". Ibid. 
ers or listeners. There are pieces for orchestra, chamber, solo, vocal, vocal-instrumental music; among others, Capriccio for clarinet and piano (1960), 6 utworów for violin and piano (1970), 6 trioletów for two flutes and piano (1979), Sonatina giocosa (1959), Tre leggerezze for piano solo (1965), 6 etiud for two pianos (1977), Żabi koncert and Na jeziorku for two-voice children choir (1984), Trzy pieśni żartobliwe for two-voice female choir, string quintet and drums with text written by Ludwik Jerzy Kern (1962), Wierszyki Pana Leara for reciter and chamber orchestra (1967), Wiersze for reciting voice and piano with the text written by Jarosław Iwaszkiewicz (1977). Many of the mentioned pieces have didactic purposes. There are written for the students of primary and high music schools. The composer considers the technical and expressive possibilities of young performers.

In vocal-instrumental works the text was an important element for Szajna-Lewandowska. She wanted to show the specific climate and character of a poem through music. In the conversation with Zofia Frąckiewicz, the composer said: "for me the source of inspiration is mainly good poetry, fascinating literary text". ${ }^{10}$ It is visible in Wiersze Pana Leara. In this piece, the creator excellently connected music with text. Musical layer, despite the fact that exist independently, was adopted to the sonoristics of the word. Tone painting is used in music, which shows the humorous and grotesque features of the text, thanks to which it stimulates the rich child's imagination.

In Szajna-Lewandowska' work there is a cycle of the songs for children written for voice and piano Władysław Broniewski’s texts, entitled Gramy w zielone. It consists of 6 pieces of the following titles: Gramy w zielone, Pierwszy motylek, Kominiarz, Wróżby, Śmigus, Kukiełka. The songs of this cycle are simple, but not banal. They have enough musical values to be the source of emotions and aesthetic expressions for a child. Pieces have the character of strophic songs, beginning with the piano introduction, which introduces the listener in the proper mood: play, grotesque or sadness. In the sphere of harmony, the composer uses fourths-thirds chords, which are freely juxtaposed. The use of

10 Z. Frąckiewicz, Wrocławscy twórcy kultury. Jadwiga Szajna-Lewandowska, "Słowo Polskie", 4-5.10.1970, p. 5; as cited in: A. Granat-Janki, Jadwiga Szajna-Lewandowska, [in:] eadem, Twórczość kompozytorów wrocławskich w latach 1945-200o, Wrocław 2003, p. 256. 
a modern harmony in the pieces devoted for children has its grounds, because it shapes the sense of future music's recipients.

Trzy pieśni żartobliwe for two-voice female choir, string quintet and drums with the text written by Ludwik Jerzy Kern is a musical grotesque for children as music to listen. It is a cycle of three songs of the following titles: Magik, Zabawa w gamy, Gitara (example 4). The whole cycle is maintained in homophonic texture. Harmony is based on the chords built on fourths and thirds. The use of dotted rhythm and frequent changes of metre are justified by the need to highlight the rhythm of the text. The part of a choir is treated like drums. The composer produces this effect through using different articulations, and introducing spoken fragments, what influences the timbre of the pieces. On the other hand, expressive sphere is characterized by humour and grotesque.

3 PIESNI ZARTOBLIWE

1. Magik

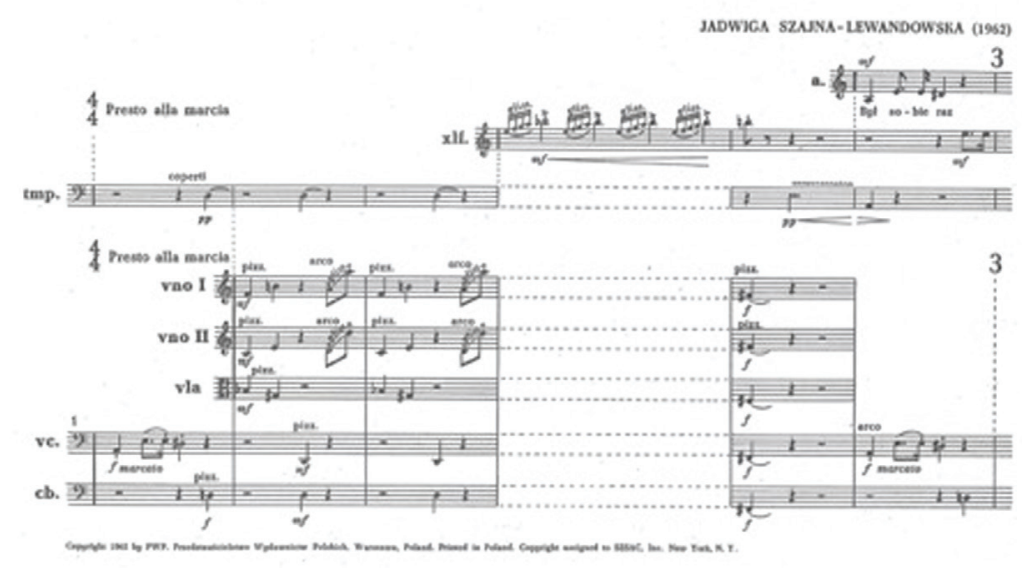

Ex. 4: Magik from the cycle Trzy pieśni żartobliwe, bb. 1-6. Source: J. SzajnaLewandowska, Trzy pieśni żartobliwe for two-voice female choir, string quintet and drums with the text written by Ludwik Jerzy Kern, Kraków 1965, p. 3.

The work of Jadwiga Szajna-Lewandowska for children has a special place in the works of huge group of Polish composers written contemporarily music for children, Her pieces for the youngest were created through the whole life, with passion, so characteristic for her, and great 
engagement. The composer is remembered as the creator of the first Polish ballet for children (Pinokio). In her works, she used the wide instrumentation, adding additional percussion instruments. Her compositional workshop confirms her openness for new solution, especially in terms of timbre and rhythm. Thanks to this, Szajna-Lewandowska's music is transparent, sophisticated and colourful. The composer also had the ability to compose texts into the stage action. Fantasy, poetry and a dose of humour are the elements, which characterize her compositions. What is significant, all elements of the works are used to achieve expressive effects.

The natural need of a child, resulting from the temperament of a young person and the will to know the world, is happiness. Its source are, without doubt, the compositions written by Jadwiga SzajnaLewandowska. This feeling results from listening to the composition. It is caused by the text of mood evoked by music. The resonate with the child's activity, with his or her need to auto-realise, to unload the gathered energy, with satisfaction connected with action and creation. The work of Szajna-Lewandowska affects, therefore, all spheres of a child's mentality, provides emotional and cognitive experiences, awakens the aesthetic sensitivity of a young man. Both pieces devoted to being performed by children and these in which children are only addressees, develop their artistic skills and imagination. To resume, Jadwiga Szajna-Lewandowska created music adequate for the youngest performers and recipients, adapted for their perceptive abilities.

\section{Bibliography}

Bukowski R., [without title], “Gazeta Robotnicza”, 11.06.1964.

Bukowski R., „Błękitny kot” Szajny-Lewandowskiej, "Wieczór Wroclawia", 7.02.1982.

Dąbrowska A., Ja widzę muzykę, "Gazeta Robotnicza”, 20.06.1974.

Dachtera K., Opera Wrocławska 1945-1995, Wrocław 1995.

Granat-Janki A., Szajna-Lewandowska Jadwiga, [in:] Encyklopedia muzyczna PWM. Część biograficzna, E. Dziębowska (ed.), Vol. 10 $(S m-S)$, Kraków 2007.

Granat-Janki A., Szajna-Lewandowska Jadwiga, [in:] Polski słownik biograficzny, Vol. 46, Warszawa-Kraków 2009-2010. 
Granat-Janki A., Twórczość kompozytorów wrocławskich w latach 1945-2000, Wrocław 2003.

Hanek L., Wrocławscy kompozytorzy, muzykolodzy i publicyści, Wrocław 1985.

Kofin E., Spektakl pełen pogody, "Słowo Polskie”, 9.03.1967.

Kofin E., Życie muzyczne Wrocławia, [in:] Panorama kultury wspótczesnego Wrocławia, B. Zakrzewski (ed.), Wrocław 1970.

Słota M., Jadwiga Szajna-Lewandowska. Katalog tematyczno-biograficz$n y$, MA thesis, Akademia Muzyczna we Wrocławiu, Wrocław 2001.

Słota M., Szajna-Lewandowska Jadwiga, [in:] Kompozytorzy polscy 1918-200o, M. Podhajski (ed.), Vol. 2, Biogramy, Gdańsk-Warszawa 2005.

Spodenkiewicz W., Sylwetki kompozytorów wrocławskich, [in:] Studia i rozprawy. Kultura muzyczna Dolnego Śląska. Przeszłość i dzień dzisiejszy, Warszawa 1970.

Szajna-Lewandowska J., Balet ten dedykowałam polskim dzieciom, [in:] Pinokio [programme of the play], Wrocław 1964.

Szajna-Lewandowska J., Głos ma kompozytor, [in:] Porwanie $w$ Tiutiurlistanie [programme of the play], Wrocław 1967.

Szajna-Lewandowska J., Wierszyki Pana Leara, [in:] VIII Wrocławski Festiwal Polskiej Muzyki Współczesnej [programe], Wrocław 1970. Węgrzyn W., Życie muzyczne we Wrocławiu i na Dolnym Śląsku, [in:] Kultura na Dolnym Śląsku, red. J. Trzynadlowski, WarszawaWrocław 1977.

Witka J., Jadwiga Szajna-Lewandowska - wizerunek własny [radio audition], Polskie Radio Wrocław, 6.07.1971. 